
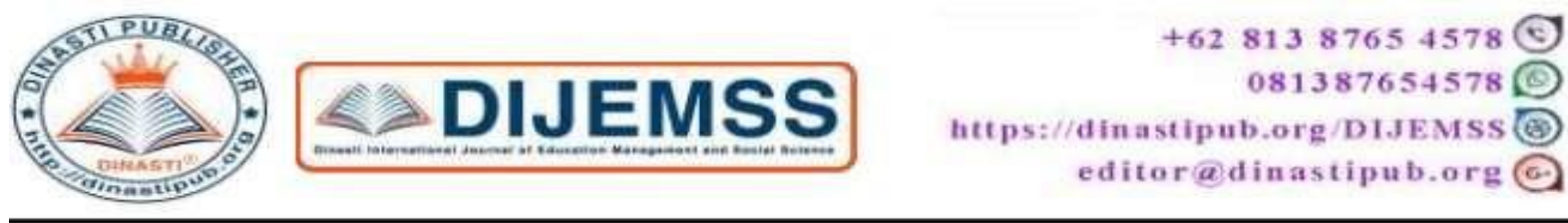

\title{
TRANSFORMATIONAL, AUTHENTIC, AND AUTHORITARIAN \\ TYPES OF LEADERSHIP: WHICH ONE IS THE MOST INFLUENTIAL IN STAFFS' PERFORMANCE (A Study on Performance In A Religious School Setting)
}

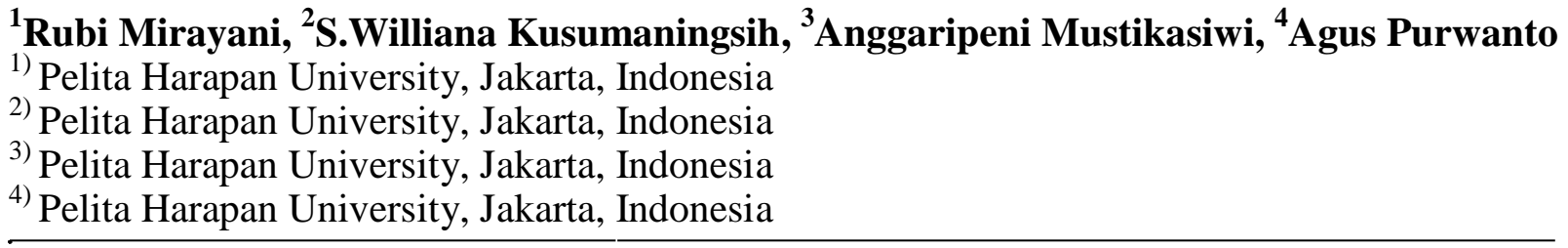

ARTICLE INFORMATION Received: 14 December 2019 Revised: 19 December 2019 Issued: 24 December 2019

Corresponding author: first author E-mail: eecuph@uph.edu

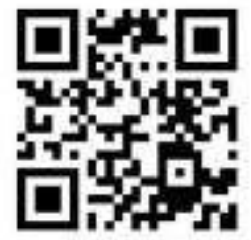

DOI:10.31933/DIJMESS
Abstract: The research conducted in a religion based school in Gading-Serpong, Jakarta was conducted to determine the significance of leadership style toward the organizational culture and motivation in order to see the influence on the staff's performance. Data obtained through questionnaires with total sampling method of 33 out of 34 employees. Data analysis is using Spearman Rank correlation analysis, correlation, and hypothesis testing. The result of the study showed that (1) the authentic leadership style is perceived higher than authoritarian and transformational leadership styles (2) The leadership style has a significant influence on the school staff's motivation. This is indicated on the result of P-value that is 0.0000.(3) The leadership style does have an influence on the organizational culture as the the $\mathrm{P}$ value between dependent variable Leadership (KP) to independent variable Performance $(\mathrm{KJ})$ with the intervening variable Culture Organization (BO) is 0.004 and it means there specific Indirect Effect is accepted since it is less than 0.005. whereas the $\mathrm{P}$ value between the dependent variable Leadership (KP) to independent variable Performance $(\mathrm{KJ})$ with the intervening variable Motivation (MO) is 0.124. (4) The leadership style has also showed to have significant influence and direct effect on the staff's performance. This is depicted by the result of the $\mathrm{P}$ values that is 0.001 , which explained that leadership has a significant and direct effect on the workers' performance, (5) The organizational culture has an influence toward the staff's performance as based on the data, from all the result of the R-square for the Organizational culture (BO) is 0.56 ; that organizational culture as the 
intervening variable by $56 \%$ and (6) the staff's motivation does not affect the staff's performance as shown on the the $\mathrm{P}$ value is 0,082 which is more than 0.05 , therefore Motivation of the staff does not affect the performance of the staff directly.

Keywords: Leadership Style, Staff's Performance, Motivation, Organizational Culture,

\section{INTRODUCTION}

The most valuable instrument for one's life time investment, education is desired by people of all social strata. They make a well and thorough calculation and selection to obtain the best education they could get. Here education does not only encompass academic development but also character building. For this reason, there have been a great number of schools, be it public or private ones, being built to meet the needs of the parents. Each of these schools normally has its own peculiar quality that will entice parents to enroll their children. Based on the Overview of Primary School by Status of Schools in 2018-2019, there are 131,867 public schools and 16,815 private schools in Indonesia. As many as $11.31 \%$ of the private schools are religious-based ones. Many of these, especially among Christians, have become parents' choice because they are considered to enforce discipline and development of other soft skills.

The scores result of National Standardized test in broad-spectrum the Christian based schools are consistently higher, therefore based on that the private Christian schools are believed to performing a distinguished education quality. Although there is a belief that Christian based schools have profound aims to be an institution that enables parents to train their children, however there are various aspects that composed an acceptable educationconduct by academic institution. The most crucial component is the functioning of the leadership aptitudes.

Leaders are like the forerunner who should inspire, direct and determine the goal also formulate the pathway of changes to enhance the condition of an institution or organization (Davies, 2005). And whether it is an education, government, business organization or whether it is a private or corporate institution they all need a competent leader. As Cobin, 2000 stated that it needs an effective leadership to successfully distinguish and shape a constructive corporate culture. When a constructive corporate culture is shaped which means that the leadership approach is functioning well, then well-motivated staffs are able to efficiently achieve a high competency and demonstrate a proper performance.

Al-Musadieqetal., 2017 in the previous study stated that the influence of the organizational factors of job design on the upgrading of staff performance evidenced to be significant with the motivating aspect of work motivation the study also found in the indirect practical relationship between organizational culture and intervening variables of work motivation.

Rivai, et al., 2018 however stated that a leader can be considered as a successful a leader if based on the measurement he is able to influence and develop those whom he leads. The good traits of a leader is caring and being sensitive to the needs of the people he leads that the subordinates are approachable and willing to discuss their dreams and hope. 
Therefore ,this study is conducted to find whether there is indirect practical relationship between organizational culture and intervening variables of work motivation or other intervening variables or leadership style that can affected the staff performance in an organizational system.

There are many kinds of model of leadership that are apparent in any organization or institution, some are very influential; yet some are horrendous and bring calamity to the institution. A religion- based school in Gading Serpong that was established since 2010 is in a stagnation stage and still experiencing ups and down, especially in the performance of the staffs. This study is conducted to see which kind of leadership that is highly effective to influence the climate culture of the institution and to affect the staffs' motivation that will bring significant impact on the performance of all staffs. In regard to the various models of leadership, this study is examining whether transformational leadership, authentic leadership or authoritarian leadership would have significantly influenced the organization culture and the staff and teachers motivational to exhibit the standardized school performance excellently.

Based on the description above, there are six objectives of the research. First is to describe the types of leadership, organizational culture, the school staffs' motivation and their performance. The second aim is to detect whether the leadership would have major effect on the school staffs' motivation. The third aim is to find out if the leadership would reveal significant effect on the organization's culture. The fourth attempt of the study is to see whether the leadership will have a significant and direct effect on the workers' performance. The fifth attempt is to study whether organization's culture partially affect the performance of the staffs. The sixth aim is to see the effect of the staffs' motivation partially and simultaneously toward the staffs' performance.

\section{LITERATURE REVIEW}

Leadership

Veithzal Rivai, et al., 2018 concluded the word leadership by its definition is the ability to influence people's behaviors to achieve certain goal in a particular situation. Leadership always correlate with social concerns that means there is interaction between the leaders with those he leads to accomplish the same purpose and target.

1. Transformational Leadership

Bass (1998) stated four transformational components: idealized influence transformational leaders conduct their lives to be admired, respected and trusted by their followers; inspirational motivation transformational leaders motivate and inspire those around them by offering meaning, optimism and enthusiasm for a vision of a future condition; intellectual stimulation: transformational leaders foster followers be creative and innovative to solve problems in new ways and to not to make assumptions; individualized consideration transformational leaders actively cultivate the potential of their followers by generating new chances for development, they consistently coaching, mentoring, and paying attention to the needs and desires of the followers, rather than monitoring their efforts. Leithwood, 2004 confirmed that all transformational style to leadership underscore emotions and norms then mutually share the basic goal to nurture the capacity progress and advanced level of one's commitment toward the organization's

objectives. 
A research by Erkutlu, 2008, compared transformational leadership with transactional leadership and stated that transformational leadership outcomes in accomplishment that exceed what is anticipated. Lowe et.al, 1996 confirmed that in a meta-analysis of 39 studies discovered that individuals who demonstrated transformational leadership were distinguished to be more effective leaders with better work products than those who demonstrated only transactional leadership. Further said that transformational leadership provokes followers to finish more than estimated and driven to surpass their selfishness and concerned more for the advantageous of the organization (Bass and Avolio, 1990; Northouse, 2001; Shamir, 1995).Krishnan (2002) also initiated transformational leadership style is certainly linked to serious value correspondence between the leader and devotee.

Therefore, this research is to find whether transformational leadership resulted as effective in comparison to authentic leadership and authoritarian leadership toward the culture of an organization, motivation of the workers that will influence significantly toward the performance of the workers, especially in a setting of a religion-based school.

2. Authentic Leadership

Besides the transformational leadership another great type of leadership is authentic leadership. Kernis, 2003 stated, that authentic leadership similar to the transformational type, has also four dimensions. Self-awareness has multilayered nature of the self that contains finding insight into the self through exposure to others and being acquainted with the impact on other, in other words self-awareness is pointed out by showing an understanding of everyone's potency and limitations. Relational transparency is the second dimension that presents authentic self to others by creating trust through openness which means willing to share the deepest emotions and thoughts while lessening improper reactions and manners. Balanced processing associates with leaders who always analyze all significant data factually before making any decision, they request notions that assessment intensely held(Walumbwa et al , 2007). The last one is internalized moral perspective, as it is, it refers to an affected and assimilated form of self-regulation guided by internal ethical standardsand principles. And the outcome of decision -making and behavior consistent with these internalizes principles.

Alavi and Gill, 2018statedthatauthentic leadership (Avolio,Luthans, \& Walumbwa, 2004; Gardner, Cogliser, Davis, \&Dickens, 2011; Gardner \& Schermerhorn, 2004; Luthans \& Avolio, 2003) has aptitudes, particularlyfor multifaceted adjustment of an organization due to the efficiencyto bring changes with several methods in the developments oforganizations. Further, according to Avolio,Gardner, Walumbwa, Luthans, and May (2004), authentic leaders haveaccomplished high levels of authenticity in their self-identity that they applied their strong conviction of set of values while evidently intermingling with others. It stated that authentic leadershipstimulates several motivational and learning ways in followers during the change process, which assist the effective execution of change. (Alaviand Gill, 2018).

Authenticity means 'know yourself' was initiated from an ancient Greek philosopher Socrates thatis with individualized experience, including self-perception of his own views, moods, wishes, inclinations, and theories (Snyder and Lopez, 2009).

The purpose of this study is to discover the competence of authentic leadership in comparison to transformational leadership and authoritarian leadership toward the 
culture of organization, the motivation of the workers to bring out the result in the performance of the workers.

3. Authoritarian Leadership

It refers to a leader's conduct of declaring strong authority and regulate coworkers and challenging unquestionable submission from them (Farh and Cheng, 2000). Muhumuza, 2015, defined the authoritarian leadership as a leadership style characterized by the leader preserving as much power and decision-making authority as possible. The leaders have composed a collection of rewards and punishments and operated threats and punishment to control inferiors, whose idea almost never been heard. Zylfijaj et.al, 2014 stated that authoritarian leadership style will not motivate the subordinates, and demand the job accomplished promptly. These leaders are believed to be controllers that the subordinates just need to bring the outcome based on the leader's specifications. Frequently, the authoritarian leader came up with solution that was not too inventive, therefore it would have lowered the follower's devotion toward the chores (Lazar, 2006). Confirmed by Li-Chuan Chu, 2014 stated the prior studies indicated that supervisors' authoritarian behavior aroused negative.

There are four significant aspects according to Cheng $(1993,1995)$ and Farh and Cheng (2000), These are (1) authority and control, means that unwilling to delegate, involve in only top-down interaction, control data so that it is doubtful, and fussily monitor juniors, (2) look down on the subordinate competence, therefore will not hear the subordinates' ideas and inputs, (3) image building, which makes the leaders to reserve their own self-respect confidently to manipulate associated notes and (4) didactic behavior, which means some demands on specific achievement and conduct and if it failed, harsh reprimands and scolds occurred that would generate negative emotions in subordinates, such as wrath, aggression, and anxiety (Farh et al., 2006; Wilkinson, 1996; Wu et al., 2003)

However, Fred Fiedler considered authoritarian leadership could to be good or as successful only at definite times in certain duty circumstances permitting for the extravagances of consideration and heartlessness (Leonard,2018; Men, 2010). The circumstances could be used pronounced Cherry (2018) when there are some untrained staff who confuse how to perform or which techniques to follow then some strong yet effective directions can be delivered through details.

\section{Motivation}

Handoko,2010 defined a motivation is accumulation of internal and external processes that produce enthusiasm when executing some activities. Motivation is a state of being in individual that stimulate the desire to achieve a certain goal. Hasibuan, 2016 confirmed that motivation is a driving force that create passion in one's mind to work together effectively and cooperatively in achieving a great satisfaction. Motivation is a mood inclination to conduct oneself that start from within and end up in self-adjustment to satisfy the motives. Kanfer et al., 2013 stated that work strength is believed as a key indicator of motivation to work as it implies to the global estimate onthe involvement of each worker.

It concludes to motivate the performance employee and cultivate the culture in the organization in different set up and conditions there are many kinds of leadership style that exist and perform around the world. Therefore, this study is to bring some knowledge of the most effective leadership style that can be used to influence the culture of an 
organization and the motivation of the employees that will significantly affected the performance of the employees.

Organizational Culture

Organization culture defined as shared values and beliefs that enable member to understand their roles in and the norms of the organization (Luthans \& Doh (2015:177). The organization's expectations, experiences and philosophy are reflected in member selfimage and works, how the organization guide members' behavior, how the members interact within the organization and outside the organization, as well as future expectations. The organization culture is based on shared beliefs, attitudes, written and written rules that had been developed over time and are considered valid (The Business Dictionary). In the context of the study where the organization is a Christian school, the organization's vision, values, norms, systems, language, assumptions, beliefs and habits had been developed and based on the Christian bible. The Christian and biblical foundation for shared set of beliefs, expectations, values, norms, and work routines that influence the members to relate to one another and work together to achieve the organizational goals (Jones \& George, 2013:61) have become the area of this study in related to how the leadership styles and members' motivation will influence the work performance.

According to Robbins \& Coulter (2014:78), the dimension of organizational culture are innovation, risk taking, attention to detail, outcome orientation, people orientation, team orientation, aggressiveness, stability and agility. These dimensions is to be studied in regard to leadership styles, motivation and work performance.

\section{Work Performance}

Amstrong \& Baron, 1998 stated that work performance is the achievement of assigned duties and related strongly with the objectives and strategies of an organization, the satisfaction of the consumers and the benefit of the economy. Abdullah, 2013 confirmed that work performance is the outcome of the hard works of the whole organization which consist of the workers who have done their works based on the job description and direction of the leaders. He added that work performance of a workers were also measured based on their competencies and skills to think quickly and solve problem accurately. Effendi (2009) has an opinion that work performance is the achievements of the workers based on the responsibility they should have shown. It also meant that the workers have displayed excellent qualities and quantities in the position and role they possessed

\section{RESEARCH METHODS}

The study is using the explanatory survey method with the quantitative approach. The data collection is using questionnaire as the instrument. Data collected is a primary data from 33 staff from the total population of 34 staff from a Christian School in Gading Serpong, Tangerang- West Java.

The descriptive statistic is used to find out the variables of leadership styles, organizational culture and motivation toward the work performance as the dependent variable. Inferential statistic is used to test the hypothesis simple regression and multiple regression analysis

techniques. 


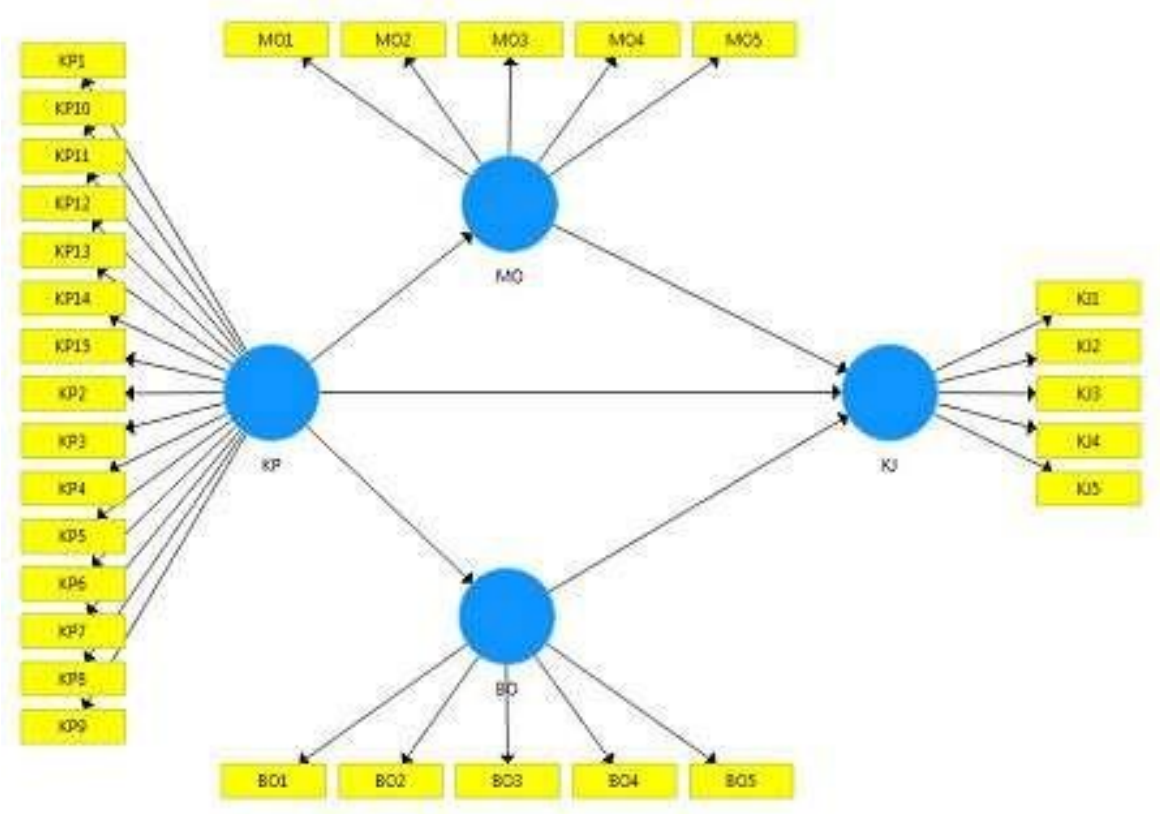

\section{FINDINGS AND DISCUSSION}

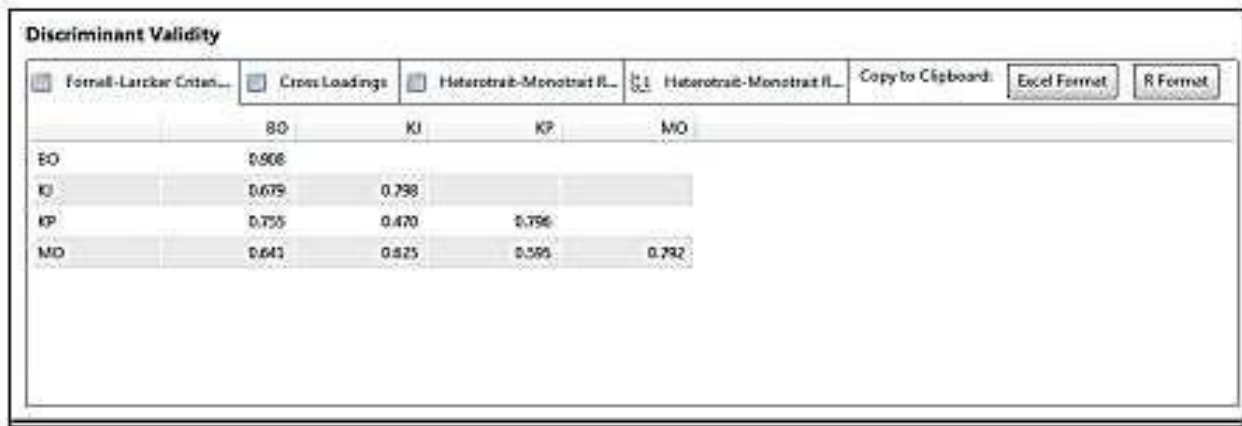

Discriminant Validity of Performance (KJ) to Culture organization (BO) is 0.679; Leadership (KP) to Culture organization (BO) is 0.755 and Leadership (KP) to Performance $(\mathrm{KJ})$ is 0.47 ; Motivation (MO) to Culture organization (BO) is 0.641 , Motivation (MO) to Performance (KJ) is 0.625 and Motivation (MO) to Leadership (KP) is 0.595 it means they are related to each other because it is less than 0.85 . Therefore, it means that discriminant validity exists between the scale measuring Performance $(\mathrm{KJ})$ and the scale measuring Culture organization (BO), between the scale measuring Leadership (KP) and the scale measuring Performance (KJ), between the scale measuring Motivation (MO) and the scale measuring Culture organization (BO), between the scale measuring Motivation (MO) and the scale measuring Performance (KJ) and measuring Motivation (MO) and the scale measuring Leadership (KP).

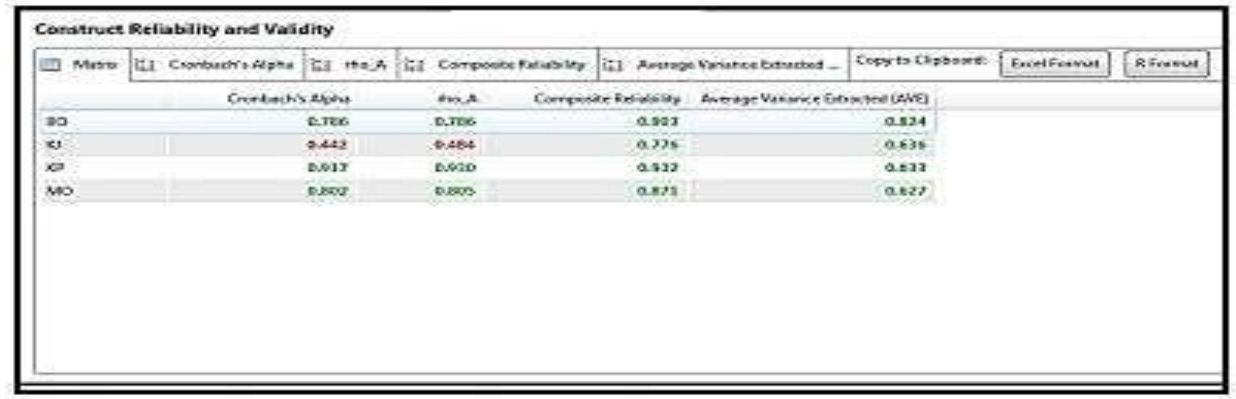


Reliability and Validity based on Cronbach's Alpha of Culture organization (BO) is 0.78; Leadership (KP) is 0.91 , Motivation (MO) 0.80 , which means they all are reliable and valid because is more than 0.05 , except for Performance $(\mathrm{KJ})$ that is 0.442 is not reliable and valid, because it's less than 0.05 .

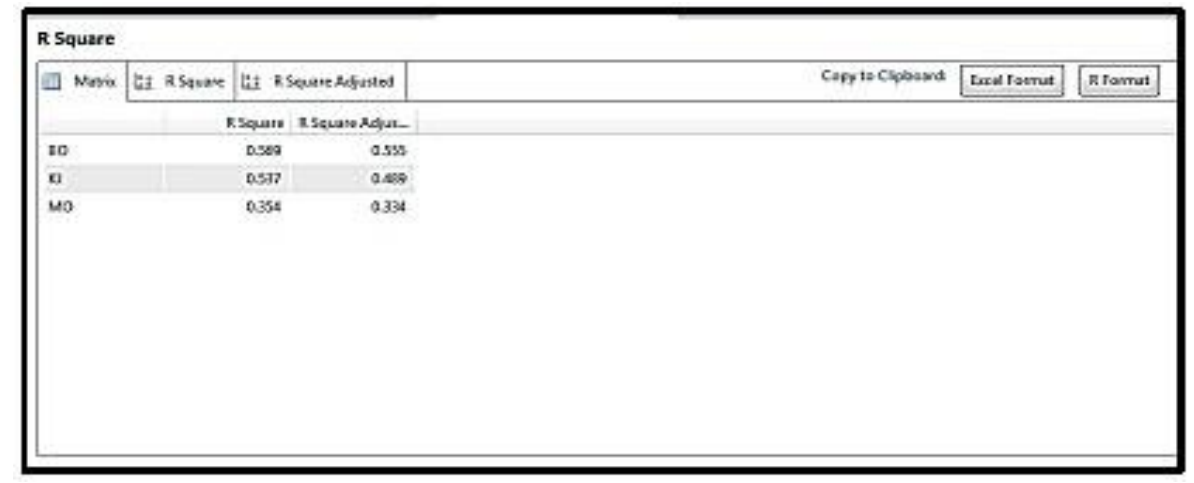

Based on the data, from all the result of the R-square, it listed that Culture organization (BO) is 0.56; Performance (KJ) is 0.53, Motivation (MO) 0.35 it means that the most appropriate to defined as the intervening variable is the Culture organization (BO) which is 0.56 of it means $56 \%$.

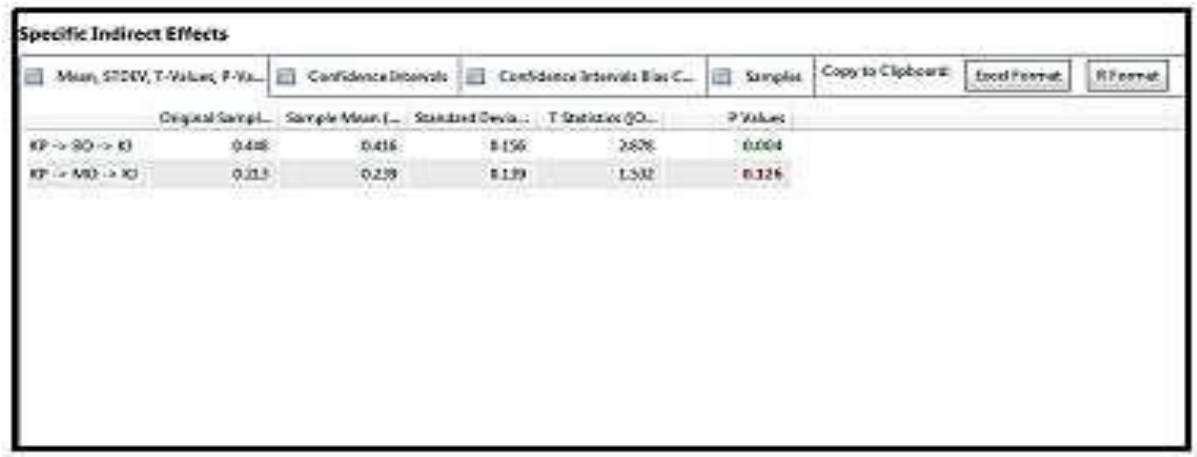

Based on the data, the $\mathrm{P}$ value between dependent variable Leadership (KP) to independent variable Performance $(\mathrm{KJ})$ with the intervening variable Culture Organization (BO) is 0.004 and it means there specific Indirect Effect is accepted since it is less than 0.005. whereas the $\mathrm{P}$ value between the dependent variable Leadership (KP) to independent variable Performance $(\mathrm{KJ})$ with the intervening variable Motivation (MO) is 0.124 , it means the indirect specific effect is not accepted, since it is more than 0.005. According to this data it means that in this school the intervening variable between Leadership style (KP) with Performance (KJ) that significantly effective is the Culture Organization (BO) which means that the leadership style carries and creates the atmosphere in the school which will build the culture of the school, that affected the performance of the staff. The leadership style that is accepted is authentic leadership that augment the performance of the workers.

\begin{tabular}{|c|c|c|c|c|c|c|c|c|}
\hline \multicolumn{9}{|l|}{ Total Effects } \\
\hline \multirow[t]{2}{*}{ Đ Mean STDE, } & 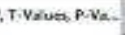 & [1] Corfiente hiterab & a conet & idonce intervats Bios C & i] smptes & Cosp to cliptones? & Coced foumat & B Formin \\
\hline & Ongnesimpl & - Samplo Maran is Stane & Lent Devis. & TStatsices ipa. & Pvatuon & & & \\
\hline $80->x J$ & 0553 & 3. $\quad 0548$ & $0.2 a n$ & 2904 & 0.003 & & & \\
\hline $\mathrm{KP} \rightarrow 60$ & ajss & 0.781 & 0.864 & 11800 & 0.000 & & & \\
\hline$K P \rightarrow k g$ & aAd & $0 \times 92$ & a:4s & 3202 & 0.001 & & & \\
\hline $\mathrm{KO} \rightarrow \mathrm{NO}$ & oses & 0002 & ous & $53 x$ & 0.000 & & & \\
\hline$M O \rightarrow x J$ & $0.15=$ & $\sin 0$ & 0206 & 2.341 & 0.062 & & & \\
\hline
\end{tabular}


Consistent with the result of processed data then the first hypothesis is whether the leadership (KP) would have major effect on the school staffs' motivation (MO) is accepted because the $P$ value is 0.000 means that the leadership (KP) style is significantly influenced the motivation (MO) of the worker. The second hypothesis is to find out if the leadership (KP) would reveal significant effect on the organization's culture (BO) is accepted because the $\mathrm{P}$ value is 0.000 means that the leadership style is significantly affected the culture organization in this place. The third hypothesis whether the leadership (KP) will have a significant and direct effect on the workers' performance $(\mathrm{KJ})$ is also accepted due to the $\mathrm{P}$ values that is 0.001 , which means leadership (KP) will have a significant and direct effect on the workers' performance (KJ). The fourth hypothesis whether organization's culture (BO) partially affect the performance $(\mathrm{KJ})$ of the staffs is accepted because the $\mathrm{P}$ value is 0.003 . The fifth hypothesis aim is to see the effect of the staffs' motivation (MO) partially and simultaneously toward the staffs' performance $(\mathrm{KJ})$ is not accepted because the $\mathrm{P}$ value is 0,082 which is more than 0.05 , therefore there Motivation of the staff is not affected the performance of the staff directly.

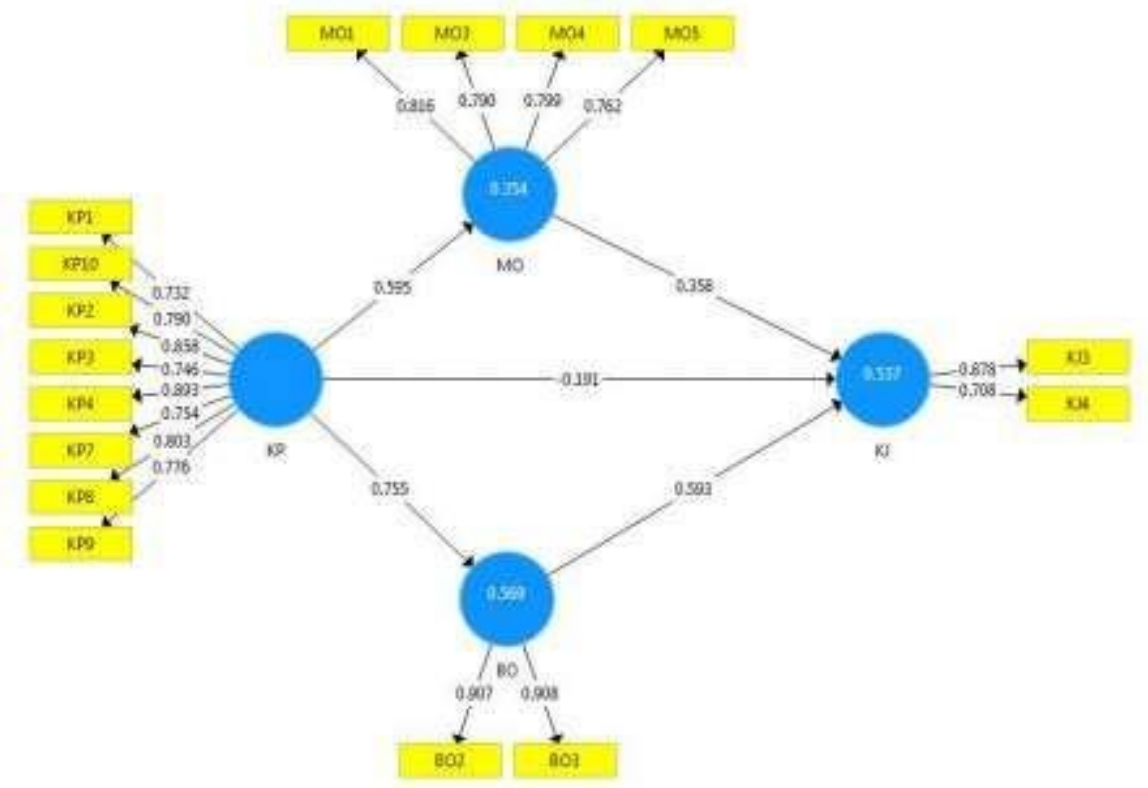

Created on the result of the data, the study discovered that the leadership style that molded the Culture organization and the motivation of the staff is Authentic leadership. There are $73 \%$ who believed that the leaders who always create genuine relationships through the connections at work which is in the dimension of Relational transparency which revealed there is an open discussion along with integrity in relations (Walumbwa, Avolio, Gardner, Wernsing, and Peterson ,2008). There are $85 \%$ of the staff perceived that the leaders listen very carefully to the ideas of others before making decisions and $\mathrm{Yu}$ and Kim, 2013 confirmed in authentic style leadership the connection between top level leaders and inferior employees is important. And there are $74 \%$ of the staff who identified that the leaders never set double standards for the team and themselves which is the application of the dimension of Internalized moral perspective that exhibits a leader's uprightness in his or her conducts based on honorable and ethics beliefs(Walumbwa et al ,2007).

Since the authentic leadership is strongly perceived it also significantly influence the culture of the school by $75 \%$ and motivation of the staff by $59 \%$, however the authentic style is not affected directly the performance of the staff. The culture of the school and the motivation of the staff functioned as intervening variables that affected indirectly the 
performance of the staff by $35 \%$ and $59 \%$. Therefore, the as a conclusion in the religious based school the most common leadership style performed in authentic style since there are some influence from the religious background that shaped the mindset of the leaders as a servant leader that should be carried and exhibited. Kiyani, et. al, 2013 reinforced that by stating that authenticity is a replication of the leader's innermost identity, then Kotzé and Nel, 2017 reconfirmed a leadership quality, has been connected to a servant and spiritual leadership.

\section{CONCLUSION AND SUGESTION}

\section{Conclusions}

Based on the result of the study on "TRANSFORMATIONAL, AUTHENTIC, AUTHORITARIAN LEADERSHIP: WHICH ONE IS THE MOST INFLUENTIAL IN THE STAFFS'PERFORMANCE. A Study on Performance in a religious setting school, the following are the conclusion:

1. The authentic leadership style is well accepted and influenced the staff's performance, in this case is for the religion-based school in Gading Serpong.

2. In regard to reliability and validity, there are significant influence between the staff's performance toward authentic leadership style that is preferred by the staff.

3. The authentic leadership and organization culture have significant influence on staff's performance.

4. Work- motivation has significantly influenced the staff performance

5. Leadership and work-motivation are both significantly influenced the staff's performance at this religious based school in Gading Serpong. This is clearly depicted on result of preferred authentic leadership style that reached $91 \%$ and work motivation : $80 \%$.

\section{Suggestions}

The result of the study has shown that among the three leadership styles; transformational, authentic, and authoritarian styles, the authentic leadership style has been as resulted as the style that influence both the staff's work motivation and organizational culture that eventually affect the staff's performance. The preferred leadership style, which in this study is authentic leadership will help the management in creating a desired organization culture and driving the staff to have better motivation and work performance.

\section{REFERENCE}

Alavi,Seyyed Babak and Gill, Carol, 2016. Leading Change Authentically: How Authentic Leaders Influence Follower Responses to Complex Change. ournal of Leadership \& Organizational Studies, Issue DOI: 10.1177/1548051816664681, pp. 115.

Al-Musadieq, Muhammad, Nurjannah, Raharjo, Kusdi,Solimun and Fernandes, Adji Achmad Rinaldo, 2018. "The mediating effect of work motivation on the influence of job design and organizational. Journal of Management Development, 10( Emerald Publishing Limited).

Anon., n.d.

Beverly Alimo-Metcalfe and Robert J. Alban-Metcalfe, 2001. The development of a new

Transformational Leadership Questionnaire. Journal of Occupational and Organizational Psychology, 74(The British Psychological Society), pp. 1-27. 
Bosch, D., 2013. The Impact of Transformational Leadership on Leader-Follower Work Value Congruence. International Journal of Business and Social Research (IJBSR),, Volume vol. 3 no 8, pp. 18-31.

Chukwusa, J., 2019. Autocratic Leadership Style: Obstacle to Success in Academic Libraries. Library Philosophy and Practice e-Journal, Issue DigitalCommons@University of Nebraska - Lincoln. Chu, L.-C., 2013. The moderating role of authoritarian leadership on the relationship between the internalization of emotional regulation and the wellbeing of employees. Leadership, Issue DOI: 10.1177/1742715013498403, p. 1-18.

Corbin, B., 2000. Entrepreneurial Leadership: Fundamentals. Carmel: Corbin Group Publishing.

Erkutlu, H., 2008. The impact of transformational leadership on organizational and leadership effectiveness. Journal of Management Development, Vol. 27 (No. 7), pp. 708-726.

Fachreza, Said Musnadi, M. Shabri Abd Majid, 2018. Pegaruh Motivasi kerja,Lingkungan Kerja,Dan Budaya Organisasi Terhadap Kinerja Karyawan Dan Dampaknya Pada Kinerja Bank. jurnal Magister Manajemen ISSN 2302-0199.

Fadhil, Achmar dan Mayowan, Yuniadi, 2018. Pengaruh Motovasi Kerja dan Kepuasan Kerja Terhadap Kinerja Karyawan AJB Bumiputra. Jurnal (JAB), vol 54 (no 1). Kotzé, Martina and Nel, Petrus, 2017. Personal factor effects on authentic leadership. Journal of Psychology in Africa, Vol. 27, No. 1(Africa Scholarship Development Enterprize), p. 47-53.

Lee, C. S., 2018. Authentic Leadership and Organizational Effectiveness: The Roles of Hope, Grit, and Growth Mindset. International Journal of Pure and Applied Mathematic, Volume 118 no 19(Special), pp. 383-401.

Mboya,Millicent Atieno, Were,Susan and Otieno,Romanus Odhiambo , Month: October 2017 - March 2018. EFFECT OF AUTOCRATIC LEADERSHIP STYLE ON QUALITY ASSURANCE IN INSTITUTIONS OF HIGHER LEARNING IN KENYA. International Journal of Management and Commerce Innovations, Volume Vol. 5, Issue 2, pp. 1214-1225.

MUHUMUZA, M. V., 2015. THE INFLUENCE OF AUTHORITARIAN LEADERSHIP ON SOCIAL, POLITICAL AND ECONOMIC DEVELOPMENT: A COMPARATIVE STUDY OF ZAMBIA AND SINGAPORE, s.l.: TECHNICAL UNIVERSITY OF KENYA.

Theodora, O., 2015. Pengaruh Motovasi Kerja Terhadap Kinerja Karyawan PT Sejahtera Motor Gemilang. Jurnal AGORA Vol 3. no 2.

ZYLFIJAJ, KUJTIM, REXHEPI, LURA and GRUBI, ARTA KOKA, 2014. Authoritarian Leadership VS. Participative Leadership in Organizations, Bologna: Studiorum University. 